$$
\begin{aligned}
& \text { College of Europe } \\
& \text { Collège d'Europe }
\end{aligned}
$$

\title{
The European Court of Justice and Process-oriented Review
}

\section{Koen Lenaerts}

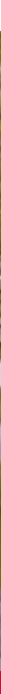

DEPARTMENT OF

EUROPEAN LEGAL STUDIES

Research Paper in Law

$01 / 2012$ 
$\underset{\text { Brugge }}{\mathbf{E}}\left|\begin{array}{l|l}\text { College of Europe } \\ \text { Collège d'Europe }\end{array}\right| \underset{\text { Natolin }}{\mid}$

European Legal Studies

Etudes Européennes Juridiques

\section{RESEARCH PAPERS IN LAW}

$1 / 2012$

Koen Lenaerts

The European Court of Justice and Process-oriented Review

(c) Koen Lenaerts, 2012

\footnotetext{
European Legal Studies/Etudes Européennes Juridiques

Dijver 11 | BE-8000 Brugge, Belgium | Tel. +32 (0)50 477261 | Fax +32 (0)50 477260

E-mail law.info@coleurope.eu | www.coleurope.eu
} 


\title{
The European Court of Justice and Process-oriented Review
}

\author{
Koen Lenaerts*
}

Structuralism is a theory of U.S. constitutional adjudication according to which courts should seek to improve the decision-making process of the political branches of government so as to render it more democratic. ${ }^{1}$ In words of John Hart Ely, courts should exercise their judicial-review powers as a 'representation-reinforcing' mechanism. ${ }^{2}$ Structuralism advocates that courts must eliminate the elements of the political decision-making process that are at odds with the structure set out by the authors of the U.S. Constitution. The advantage of this approach, U.S. scholars posit, lies in the fact that it does not require courts to second-guess the policy decisions adopted by the political branches of government. Instead, they limit themselves to enforcing the constitutional structure within which those decisions must be adopted. Of course, this theory of constitutional adjudication, like all theories, has its shortcomings. For example, detractors of structuralism argue that it is difficult, if not impossible, to draw the dividing line between 'substantive' and 'structural' matters. ${ }^{3}$ In particular, they claim that, when identifying the 'structure' set out by the authors of the U.S. Constitution, courts necessarily base their determinations not on purely structural principles, but on a set of substantive values, evaluating concepts such as democracy, liberty and equality. ${ }^{4}$

Without claiming that structuralism should be embraced by the ECJ as the leading theory of judicial review, the purpose of my contribution is to explore how recent case-law reveals that the ECJ has also striven to develop guiding principles which aim to improve the way in which the political institutions of the EU adopt their decisions. In those cases, the ECJ decided not to second-guess the appropriateness of the policy choices made by the EU legislator. Instead, it preferred to examine

\footnotetext{
* Judge and President of Chamber at the European Court of Justice, and Professor of European Union Law, Leuven University. All opinions expressed herein are personal to the author.

${ }^{1}$ See generally S.A. Barber and J.E. Fleming, Constitutional Interpretation: The Basic Questions (Oxford, OUP, 2007)

${ }^{2}$ See United States v Carolene Products Company, 304 U.S. 144 (1938), footnote four. See, notably, J.H. Ely, Democracy and Distrust (Cambridge, Harvard University Press, 1980).

${ }^{3}$ L.H. Tribe, 'The Puzzling Persistence of Process-Based Constitutional Theories' (1980) 89 Yale Law Journal 1063.

${ }^{4}$ A. Barber and J.E. Fleming, above $\mathrm{n}$ 1, at 121 (who argue that '[i]f the cases manifesting "structuralism" show anything, they show a history, perhaps a tradition, of disagreement over structural questions. They show that judges can't solve structural questions by pointing to structures').
} 
whether, in reaching an outcome, the EU political institutions had followed the procedural steps mandated by the authors of the Treaties. Stated simply, I argue that judicial deference in relation to 'substantive outcomes' has been counterbalanced by a strict 'process review'. To that effect, I would like to discuss three recent rulings of the ECJ, delivered after the entry into force of the Treaty of Lisbon, where an EU policy measure was challenged indirectly, i.e. via the preliminary reference procedure, namely Vodafone, Volker und Markus Schecke and Test-Achats. ${ }^{5}$ Whilst in the former case the ECJ ruled that the questions raised by the referring court disclosed no factor of such a kind as to affect the validity of the challenged act, in the latter cases the challenged provisions of an EU act were declared invalid.

\section{The importance of the prior assessment of the different policy choices available}

In Vodafone, four of the leading European mobile operators, Vodafone, Telefónica O2, T-Mobile and Orange (the 'applicants'), challenged the provisions adopted by the UK which implemented Regulation No $717 / 2007^{6}$ (the 'Roaming Regulation'). ${ }^{7}$ That Regulation lays down maximum charges that mobile operators may levy for voice calls made and received by users outside their own network (this is known as the 'Euro-tariff'). ${ }^{8}$ The Roaming Regulation also lays down the maximum price that the consumer's operator must pay to the foreign operator when that consumer uses the latter operator's network (this is known as the 'wholesale roaming charges'). Additionally, mobile operators are obliged to provide information about roaming charges to customers. ${ }^{9}$

The High Court referred two questions on the validity of the Roaming Regulation to the ECJ. First, it asked whether ex Article 95 EC (now Article 114 TFEU) was an adequate legal basis to adopt the Roaming Regulation. Second, it

\footnotetext{
${ }^{5}$ See C-58/08 Vodafone and Others, judgment of 8 June 2010, not yet reported; Joined Cases C92 and 93/09 Volker und Markus Schecke GbR, judgment of 9 November 2010, not yet reported; Case C-236/09 Association belge des Consommateurs Test-Achats and Others, judgment of 1 March 2011, not yet reported.

${ }^{6}$ OJ [2007] L 171/32. That Regulation has been amended by Regulation No 544/2009, OJ [2009] L $167 / 12$, so that now the imposition of maximum wholesale and retail prices also applies for SMS and data roaming.

${ }^{7}$ See Article 4 of the Roaming Regulation.

${ }^{8}$ See Article 3 of the Roaming Regulation.

${ }^{9}$ See Article 6 of the Roaming Regulation.
} 
also wished to know whether, by imposing a Euro-tariff, the EU legislator had violated the principles of proportionality and/or subsidiarity.

The ECJ began by recalling the conditions that must be met in order for the EU legislator to rely on ex Article 95 EC (now Article 114 TFEU). ${ }^{10}$ First, 'a mere finding of disparities between national rules and the abstract risk of infringements of fundamental freedoms or distortion of competition is not sufficient to justify the choice of [ex] Article 95 EC [now Article 114 TFEU] as a legal basis'. In addition, those disparities must 'obstruct the fundamental freedoms and thus have a direct effect on the functioning of the internal market'. ${ }^{11}$ Secondly, ex Article 95 EC (now Article 114 TFEU) may be relied upon prospectively, i.e. so as to 'to prevent the emergence of such obstacles to trade resulting from the divergent development of national laws', provided that that emergence is likely to happen and that the EU measure in question is designed to prevent it. ${ }^{12}$ Thirdly, '[w] here an act based on [ex] Article 95 EC [now Article 114 TFEU] has already removed any obstacle to trade in the area that it harmonises, the [EU] legislature cannot be denied the possibility of adapting that act to any change in circumstances or development of knowledge having regard to its task of safeguarding the general interests recognised by the Treaty'. ${ }^{13}$ Fourthly, the ECJ recalled that the EU legislator enjoys discretion in relation to the method of approximation most appropriate for achieving the desired result. ${ }^{14}$ Last but not least, nothing prevents the EU legislator from adopting harmonising measures which seek to ensure a high level of consumer protection and a high level of competition, in so far as the conditions for having recourse to ex Article 95 EC (now Article 114 TFEU) are fulfilled. ${ }^{15}$

As to the case at hand, the ECJ noted that prior to the adoption of the Roaming Regulation the level of charges for international roaming services was high. This was due to the high wholesale charges levied by the foreign operators as well as to the high retail mark-ups charged by the home operator. ${ }^{16}$ The relationship between costs and roaming prices, the ECJ observed, was not that of a fully

\footnotetext{
${ }^{10}$ Vodafone and Others, above $\mathrm{n} 5$, paras 32 to 36.

${ }^{11}$ See e.g. Case C-380/03 Germany v Parliament and Council [2006] ECR I-11573; Case C-376/98 Germany v Parliament and Council [2000] ECR I-8419, paras 84 and 106.

${ }^{12}$ See e.g. Case C-301/06 Ireland v Parliament and Council [2009] ECR I-593, para. 64.

${ }^{13}$ See e.g. Case C-491/01 British American Tobacco (Investments) and Imperial Tobacco [2002] ECR I-11453, paras 77 and 78 .

${ }^{14}$ See Case C-217/04 United Kingdom v Parliament and Council [2006] ECR I-3771, para. 43.

${ }^{15}$ See e.g. Cases C-154/04 and C-155/04 Alliance for Natural Health and Others [2005] ECR I6451, para. 30.
} 
competitive market. In addition, the tools with which the National Regulatory Authorities (the 'NRAs') had been provided by Directive $2002 / 21^{17}$ were insufficient to take effective and decisive action with regard to the high level of wholesale prices for roaming services. ${ }^{18}$ For example, a French NRA could not control the high wholesale roaming charges levied by a mobile operator located in Spain. Moreover, there was an increasing pressure for the Member States to solve the high level of retail charges for EU-wide roaming services. According to the explanatory memorandum and the Impact Assessment Report (the 'IAR'), such national measures - based on the Member States' residual competences as regards consumer protection rules - would have led to a divergent development of national laws. ${ }^{19}$ In order to correct that situation, the ECJ held that the EU legislator was entitled to adopt a specific ex ante regulatory measure which would take into account the unique characteristics of the roaming markets and seek to maintain competition among mobile operators, namely the imposition of a price ceiling for the retail and wholesale charges made for roaming services.

As to the principle of proportionality, the question was whether, by laying down a Euro-tariff, the Roaming Regulation breached that principle. To begin with, the ECJ recalled that, when exercising its legislative powers involving political, economic, and social choices of great complexity, the Union enjoys broad discretion. Only where an EU measure is manifestly inappropriate to the objectives it pursues will the ECJ rule that it is contrary to the principle of proportionality. ${ }^{20}$ Yet, the ECJ pointed out that the exercise of such discretion must be based on objective criteria. ${ }^{21}$ Next, the ECJ proceeded to determine whether the imposition of a Euro-tariff was appropriate for the purpose of protecting consumers against high levels of charges. It replied in the affirmative. Had the EU legislator limited itself to fixing maximum prices for the wholesale market, the retail charges for EU-wide roaming services would not have been reduced. The ECJ observed that the imposition of a Euro-tariff aimed to ensure 'a more reasonable reflection of the underlying costs involved in the provision of those services than ha[d] been the case'. ${ }^{22}$ Indeed, as the IAR points out, the average retail price for a roaming call was five times higher than the actual cost of

\footnotetext{
${ }^{16}$ Vodafone and Others, above n 5, para. 39.

${ }^{17}$ [2002] OJ L 108/33.

${ }^{18}$ Vodafone and Others, above n 5, para. 42.

${ }^{19}$ Ibid., para. 45.

${ }^{20}$ Ibid., para. 52.

${ }^{21} \mathrm{Ibid} .$, para. 53.

${ }^{22}$ Ibid., para. 57.
} 
providing the wholesale service. ${ }^{23}$ Next, the ECJ examined whether the measure at issue was necessary. The applicants argued that the Roaming Regulation should have been limited to fixing wholesale charges, whilst leaving to the rules of supply and demand the fixing of prices in the retail market. Where there was a market failure, the applicants posited, the NRAs could intervene. However, the ECJ disagreed. As recital 14 and the IAR state, 'experience has shown that reductions in wholesale prices for [EU]-wide roaming services may not be reflected in lower retail prices for roaming owing to the absence of [competitive] incentives for this to happen'. The ECJ also stressed that 'only the regulation of retail charges could improve the situation of consumers directly'. ${ }^{24}$ Hence, in light of the broad discretion enjoyed by the EU legislator, it was legitimate for the latter to set out a scheme regulating both the wholesale and the retail markets. ${ }^{25}$ Moreover, the measure at issue was proportionate in so far as it was limited in time. Article 13 of the Roaming Regulation contained a 'sunset clause', i.e. that Regulation was to expire on 30 June $2010 .^{26}$

As to the principle of subsidiarity, the ECJ focused on the imposition of a Euro-tariff. In contrast to the position on the retail market, it was clear that Member States lacked the regulatory competence in the wholesale market, since a Member State could not impose a price ceiling on a mobile operator located in another Member State. Accordingly, in relation to the wholesale market, the fact that the Roaming Regulation complied with the principle of subsidiarity was self-evident. Regarding the Euro-tariff, the ECJ observed that the Roaming Regulation sought to contribute to the smooth functioning of the internal market, by allowing operators to act within a single and coherent regulatory framework. To that end, the EU legislator was entitled to adopt harmonising measures which prevented diverging national laws from disrupting that framework. Accordingly, given the interdependence between the wholesale and retail roaming markets, a regulatory framework limited to one of those

\footnotetext{
${ }^{23}$ Ibid., para. 58.

24 Ibid., para. 66.

${ }^{25}$ Ibid., para. 68

${ }^{26}$ Ibid., para. 69. However, see Article 13 as amended by Regulation 544/2009, above n 6, which now provides that the Roaming Regulation is to expire on 30 June 2012. Moreover, it is true that, in accordance with paragraph 69 of the judgment, the ECJ appears to introduce a threepronged proportionality test, whereby, in addition to the 'suitability' and 'necessity' tests, the ECJ also balances the objective pursued by the measure in question against the economic burdens imposed on mobile operators. However, see Brenncke, Case Note (2010) 47 Common Market Law Review 1793, at 1811, who observes that the ECJ did not apply a substantive test of proportionality stricto sensu, but limited itself to ruling that the measures at issue were proportionate in light of the importance of the objective pursued and the limited duration of the intervention.
} 
two markets would have turned out to be insufficient to ensure the smooth functioning of the internal market in roaming services. Hence, a joint regulatory intervention in both markets was required and would be best achieved at EU level. ${ }^{27}$

Vodafone is an interesting example that shows how the ECJ applies the principle of proportionality in a procedural fashion. Instead of second-guessing the merits of the substantive choices made by the EU legislator, the ECJ preferred to make sure that lawmakers had done their work properly: the EU legislator had to show before the ECJ that it had taken into consideration all the relevant interests at stake. In so doing, the ECJ stressed the importance of the preparatory study carried out by the Commission, in which the latter institution showed that it had examined different regulatory options and assessed their economic, social and environmental impact, before deciding to impose a price ceiling in the retail roaming market. ${ }^{28}$ In the Commission's own words, the impact assessment is the process of systematic analysis of the likely impacts of intervention by public authorities. It is as such an integral part of the process of designing policy proposals and making decisionmakers and the public aware of the likely impacts'. ${ }^{29}$ Indeed, in its judgment, the ECJ referred to the findings set out in the IAR on six occasions ${ }^{30}$ and to those laid down in the explanatory memorandum on five. ${ }^{31}$ As Brenncke notes, it seems that '[the] more the $[E C J]$ requires from the Commission in procedural terms, $[\ldots]$ the more it will alleviate the marginal judicial review of the substantive issues which a "manifestly inappropriate" standard entails'. ${ }^{32}$

The application of 'procedural proportionality' in Vodafone is, in my view, a positive development in the case-law of the ECJ on the sensitive issue of the vertical allocation of powers. It is worth noting that it is the first time ever that the ECJ has expressly relied on the IAR when examining the compatibility of an EU policy measure with the principle of proportionality. ${ }^{33}$ In order to determine whether the challenged act is ultra vires or intra vires, the ECJ should not limit its scrutiny to a formal reading of the preamble thereof, but it should undertake a close examination

\footnotetext{
${ }^{27}$ Vodafone and Others, above $\mathrm{n} 5$, paras 76 to 78.

${ }^{28}$ See M. Brenncke, above $\mathrm{n} 26$, at 1809.

${ }^{29}$ Communication from the Commission on impact assessment, COM (2002) 276 final, which has been recently redrafted by the Commission's Impact Assessment Guidelines, SEC (2009) 92.

${ }^{30}$ Vodafone and Others, above $\mathrm{n} 5$, paras 45, 55, 58 and 65 (three times).

${ }^{31}$ Ibid., paras 39, 43, 45, 59 and 63.

${ }^{32}$ M. Brenncke, above $n$ 26, at 1809-1810.

${ }^{33}$ A. Alemanno, 'A Meeting of Minds on Impact Assessment' (2011) 17 European Public Law 485, at 502 .
} 
of the explanatory memorandum and, notably, of the IAR. I concur with Craig in that the elaboration of an IAR does not exempt the ECJ from checking whether the conditions for having recourse to Article 114 TFEU, as a legal basis, have been met. However, he correctly posits that the IAR does provide a helpful framework within which to address 'competence creep' or 'competence anxiety' concerns. ${ }^{34}$ In his view, 'if the justificatory reasoning to this effect in the [IAR] is wanting, then the ECJ should invalidate the relevant instrument, and thereby signal to the political institutions that the precepts in the Treaty are to be taken seriously'. ${ }^{35}$

This is precisely what the ECJ had previously done in Spain $v$ Council. ${ }^{36}$ In that case, Spain challenged the validity of the new Community support system for cotton adopted by Regulation No 1782/2003 on the ground that that system would produce effects that ran directly counter to the avowed aims of supporting cotton production and ensuring that cotton was not driven out by other crops in those regions where cotton was important for the agricultural economy. In particular, Spain argued that Regulation No 1782/2003 was in breach of the principle of proportionality, given that, by fixing the amount of the specific aid for cotton at $35 \%$ of the total existing aid under the previous scheme, the Commission had not taken into account labour costs and thus, the new scheme was unable to guarantee the profitability of cotton producers. The ECJ sided with Spain. After acknowledging that the EU legislator enjoys broad discretion when adopting acts pertaining to the Common Agricultural Policy (the 'CAP'), the ECJ held that such discretion does not exempt the EU institutions which have adopted the act in question from 'show[ing] before the [ECJ] that in adopting the act they actually [took] into consideration all the relevant factors and circumstances of the situation the act was intended to regulate'. ${ }^{37}$ Accordingly, 'the institutions must at the very least be able to produce and set out clearly and unequivocally the basic facts which had to be taken into account as the basis of the contested measures of the act and on which the exercise of their discretion depended'. ${ }^{38}$ Hence, since neither the Council nor the Commission had provided sufficient factual input to back-up their decision to fix the amount of the specific aid for cotton at 35\%, the ECJ had no choice but to annul the contested Regulation.

\footnotetext{
${ }^{34}$ P. Craig, 'The ECJ and ultra vires action: A conceptual analysis' (2011) 48 Common Market Law Review 395.

${ }^{35} \mathrm{Ibid}$., at 412.

${ }^{36}$ Case C-310/04 Spain v Council [2006] ECR I-7285.

${ }^{37}$ Ibid., para. 122

${ }^{38}$ Ibid., para. 123
} 
Moreover, judicial reliance on the IAR is not always possible. For example, it is difficult to take into consideration the IAR where the Council and the European Parliament have made amendments to the Commission's proposal. The fact that the Council and the European Parliament departed from the IAR does not mean, however, that the contested measure is contrary to the principle of proportionality. Otherwise, if the Council and the European Parliament were bound by the IAR, the principle of institutional balance would be called into question. ${ }^{39}$ Yet, Alemanno notes that, in such a case, the Council and the European Parliament are compelled, by virtue of the 2003 IIA on Better Lawmaking, ${ }^{40}$ to carry out their own IAR on the proposed amendments to the Commission's proposal. ${ }^{41}$ In Afton Chemical, the ECJ took a more limited approach: it just required those amendments to be based on scientific data, but it did not require an IAR. ${ }^{42}$

In summary, Vodafone shows how ex ante legislative assessment and ex post judicial review may contribute to a more rational law-making. Most importantly, Vodafone demonstrates that, by basing its reasoning on the IAR, the ECJ gives important incentives to the EU legislator to investigate alternative mechanisms and policies seriously. ${ }^{43}$

\section{Procedural Proportionality and Fundamental Rights}

Volker und Markus Schecke is another interesting case where the ECJ decided to carry out a 'process review' of the contested EU measure. Just as in Vodafone, the ECJ also applied the principle of proportionality in a procedural fashion. However, in contrast to Vodafone, the principle of proportionality did not operate as a constitutional tool designed to protect the Member States from an EU 'competence creep'. In Volker und Markus Schecke, the principle of proportionality was relied upon in order to protect individual liberty against arbitrary encroachments by public authorities.

\footnotetext{
${ }^{39}$ See, in this regard, the Opinion of AG Kokott in Case C-343/09 Afton Chemical, delivered on 6 May 2010, not yet reported, paras 85 and 86.

${ }^{40}$ See Interinstitutional agreement on better law-making, [2003] OJ C321/1.

${ }^{41}$ A. Alemanno, above $\mathrm{n} 33$, at 503.

${ }^{42}$ Case C-343/09 Afton Chemical, judgment of 8 July 2010, not yet reported, paras 49 to 51, and 57 to 59.

${ }^{43}$ A. Meuwese and P. Popelier, 'Legal Implications of Better Regulation: A Special Issue' (2011) 17 European Public Law 455, at 463.
} 
Volker und Markus Schecke was decided after the entry into force of the Treaty of Lisbon. Consequently, the ECJ had recourse to the Charter not only as an aid to interpretation, but as primary EU law. ${ }^{44}$ Hence, the principle of proportionality was applied as defined by Article 52 of the Charter, which states that '[s]ubject to the principle of proportionality, limitations may be made only if they are necessary and genuinely meet objectives of general interest recognised by the Union or the need to protect the rights and freedoms of others'.

The facts of that case may be summarised as follows. The referring court asked, in essence, whether Council Regulation No 1290/2005 ${ }^{45}$ and Commission Regulation No 259/2008 ${ }^{46}$ were compatible with Articles 7 (right to respect for his or her private and family life, home and communications) and 8 (right to the protection of personal data) of the Charter. Article 44a of Council Regulation No 1290/2005, on the financing of the common agricultural policy, provided that Member States had to ensure annual ex post publication of the beneficiaries of the EAGF and the EAFRD and the amounts received per beneficiary under each of these Funds. That information had to be the subject of a 'general publication'. For its part, Commission Regulation No 259/2008 set out the content of the publication, adding that the municipality where the beneficiary resides or is registered and, where available, the postal code or the part thereof identifying the municipality' also had to be published. Article 2 of that regulation prescribed that the information was to be made available on a single website per Member State so that it could be consulted by means of a search tool.

In relation to the existence of an interference with the rights recognised by Articles 7 and 8 of the Charter, the ECJ held that the 'publication on a website of data naming those beneficiaries and indicating the precise amounts received by them thus constitutes an interference with their private life within the meaning of Article 7 of the Charter'. ${ }^{47}$ In addition, the ECJ ruled that the publication required by Article $44 \mathrm{a}$ of

\footnotetext{
${ }^{44}$ See Article 6 TEU.

45 [2005] OJ L 209/1, as amended by Council Regulation (EC) No 1437/2007 of 26 November 2007, [2007] OJ L 322/1 ('Regulation No 1290/2005').

${ }^{46}$ Commission Regulation (EC) No 259/2008 of 18 March 2008 laying down detailed rules for the application of Regulation No 1290/2005 as regards the publication of information on the beneficiaries of funds deriving from the European Agricultural Guarantee Fund (EAGF) and the European Agricultural Fund for Rural Development (EAFRD), [2008] OJ L 76/28 ('Regulation No 259/2008').

${ }^{47}$ Volker und Markus Schecke and Eifert, above n 5, para. 58.
} 
Regulation No 1290/2005 and Regulation No 259/2008 constitutes the processing of personal data falling under Article $8(2)$ of the Charter. ${ }^{48}$

As to the justification of the interference with the rights recognised by Articles 7 and 8 of the Charter, the ECJ ruled that it is common ground that the interference arising from the publication on a website of data by name relating to the beneficiaries concerned must be regarded as 'provided for by law' within the meaning of Article 52(1) of the Charter. Articles 1(1) and 2 of Regulation No 259/2008 expressly provide for such publication'. ${ }^{49}$ Stated differently, limitations on the fundamental rights recognised by the Charter, which are grounded in a Council Regulation, must be considered as 'provided for by law'. It follows that Article 52(1) of the Charter does not require limitations on fundamental rights to be grounded in an EU measure whose adoption is conditioned upon the European Parliament's co-decision.

In that regard, Article 52(1) of the Charter states that any limitation on the rights thereof must comply with the principle of proportionality. It is thus for the EU institutions and, as the case may be, for the national authorities participating in the implementation of EU law, to verify that any limitation on fundamental rights is suitable to meet the 'objectives of general interest recognised by the Union' and 'the need to protect the rights and freedoms of others'; and that it does not go beyond what is necessary for achieving the legitimate aim pursued. In Volker und Markus Schecke, the ECJ found that the publication on a website of the names of the beneficiaries of aid from the EAGF and the EAFRD and of the amounts which they receive from those Funds was liable to increase transparency with respect to the use of the agricultural aid concerned. The ECJ reasoned that such display of information reinforced public control of the use to which that money is put and contributes to the best use of public funds. ${ }^{50}$ However, regarding the necessity of the publication in question, the ECJ held that it went beyond what was necessary for achieving the legitimate aims pursued, given that neither the Council nor the Commission had 'sought to strike [the right] balance between the European Union's interest in guaranteeing the transparency of its acts and ensuring the best use of public funds, on the one hand, and the fundamental rights enshrined in Articles 7 and 8 of the Charter, on the other'. ${ }^{51}$ Indeed, derogations and limitations in relation to the

\footnotetext{
${ }^{48}$ Ibid, para. 60.

${ }^{49}$ Ibid, para. 66.

${ }^{50}$ Volker und Markus Schecke and Eifert, above n 5, para. 75.

${ }^{51}$ Ibid, para. 80.
} 
protection of personal data must apply only in so far as they are strictly necessary. ${ }^{52}$ Thus, the Council and the Commission should have examined whether the legitimate objective pursued by the contested regulations could not be achieved by measures which interfere less with the right of the beneficiaries concerned to respect for their private life in general and the protection of their personal data in particular. ${ }^{53}$ Accordingly, the ECJ ruled that Article 44a of Regulation No 1290/2005 and Regulation No 259/2008 were invalid.

One may draw three important conclusions from Volker und Markus Schecke. First, by declaring invalid Article 44a of Regulation No 1290/2005 and Regulation No 259/2008, the ECJ showed, once again, that it takes the protection of fundamental rights seriously. Second, Volker und Markus Schecke also seems to confirm that, in the realm of fundamental rights protection, the standard of review applied by the ECJ is always the same, and does not vary depending on whether the contested measure has been adopted by the EU or by the Member States when they implement EU law. Indeed, the requirements for a limitation on a fundamental right to be compatible with the Charter, laid down in Article 52 thereof, do not distinguish between the EU or the national origin of that limitation. Finally, and most importantly for the purposes of our discussion, in Volker und Markus Schecke, the ECJ found that, as opposed to the measure in question in Vodafone, neither the Council nor the Commission had done their preparatory work properly. The contested Regulations were deemed incompatible with the principle of proportionality because those two institutions had failed to examine whether there were alternatives which, whilst attaining the objectives pursued, interfered less with the fundamental rights of the beneficiaries concerned. For example, the Council and the Commission should have examined whether limiting the publication of data by name relating to the beneficiaries of the EAGF and the EAFRD to the periods for which they received aid, or the frequency or nature and amount of aid received, was enough. It is true that the ECJ seems to suggest that such a limited publication 'would protect some of the beneficiaries concerned from interference with their private lives, [whilst providing] citizens with a sufficiently accurate image of the aid granted by the EAGF and the EAFRD to achieve the objectives of that legislation'. ${ }^{54}$ However, the findings of ECJ are not conclusive in this respect. It was left for the Council and the Commission, when

\footnotetext{
${ }^{52}$ Case C-73/07 Satakunnan Markkinapörssi and Satamedia [2008] ECR I-9831, para. 56

${ }^{53}$ Volker und Markus Schecke and Eifert, above n 5, para. 78, and paras 81 to 86.

${ }^{54}$ Ibid., para. 83.
} 
adopting a new Regulation, to determine whether such limited publication could actually guarantee the objectives they pursue.

\section{The Importance of Consistency}

In Vodafone and in Volker und Markus Schecke, the principle of proportionality was applied internally. The question whether the purposes invoked by the EU legislator were genuine did not arise. For example, in Volker und Markus Schecke, no one called into question whether the EU legislator was really seeking to enhance transparency with respect to the use of the agricultural aid concerned and to reinforce public control of the use of that money. By contrast, in Test-Achats, the ECJ was confronted with that very question. A close reading of that case reveals that the contested EU provision was declared invalid because there was a contradiction between that provision and the objectives pursued by the EU act of which it formed part. The contested EU provision did not comply with the external aspects of the principle of proportionality, i.e. it was not consistent.

In that case, the referring court asked the ECJ whether Article 5(2) of Directive $2004 / 113,{ }^{55}$ was valid in light of the principle of equal treatment between men and women. Article 5(1) of Directive 2004/113 implements that principle in relation to 'actuarial factors'. It provides that the differences in premiums and benefits arising from the use of sex as a factor in the calculation thereof must be abolished by 21 December 2007 at the latest. By way of derogation, the second paragraph of Article 5 of Directive 2004/113 stated that it was permitted for the Member States to introduce proportionate differences in individuals' premiums and benefits where the use of sex was a determining factor in the assessment of risk based on relevant and accurate actuarial and statistical data. ${ }^{56}$ If a Member State made use of that option, its decision had to be reviewed five years after 21 December 2007, account being taken of a Commission report.

At the outset, the ECJ noted that Directive 2004/113 expressly refers to Articles 21 and 23 of the Charter. Accordingly, the validity of Article 5(2) of Directive

\footnotetext{
55 [2002] OJ L 373/27. Directive 2004/133 implements the principle of equal treatment between men and women in the access to and supply of goods and services.

56 This meant, for example, that national law could allow car insurance companies to impose higher premiums on men than on women given that, in accordance with statistical data, men have a higher risk of being in a car accident than women.
} 
2004/113 had to be determined in light of those two provisions. Next, the ECJ looked at the Treaty provisions which define the principle of equal treatment between men and women as a social objective to be attained by the European Union, namely the second subparagraph of Article 3(3) TEU and Articles 8, 19(1) and 157(1) TFEU. In this regard, the ECJ pointed out that [i]n the progressive achievement of that equality, it is the EU legislature which [...] determines when it will take action, having regard to the development of economic and social conditions within the European Union'. ${ }^{57}$ This meant, for example, that, since the use of actuarial factors related to sex was a widespread practice in the Member States, it was permissible for the EU legislator to provide for the appropriate transitional period. This was actually the rationale underpinning Article 5(1) of Directive 2004/113 which sets 21 December 2007 as the deadline for the implementation of the principle of equal treatment between men and women in relation to actuarial factors. By contrast, the ECJ noted that Article 5(2) contained a derogation from that principle which was subject to no temporal limitation. '[G]iven that Directive $2004 / 113$ is silent as to the length of time during which those differences may continue to be applied', the ECJ observed, 'Member States which have made use of the option are permitted to allow insurers to apply the unequal treatment without any temporal limitation'. ${ }^{58}$

The Council argued in favour of the validity of Article 5(2) of Directive 2004/133, by pointing out that, in the context of certain branches of private insurance, the respective situations of male and female policyholders may not be regarded as comparable, given that, in light of statistical data, the levels of insured risk may be different for men and for women. However, the ECJ took a different view. In accordance with its Recitals 18 and 19, Directive 2004/133 favoured the application of rules of unisex premiums and benefits. For the ECJ, 'Directive 2004/113 is based on the premise that [...] the respective situations of men and women with regard to insurance premiums and benefits contracted by them are comparable'. ${ }^{59}$

Accordingly, Article 5(2) of Directive 2004/113, 'which enable[d] the Member States in question to maintain without temporal limitation an exemption from the rule of unisex premiums and benefits, work[ed] against the achievement of the objective of equal treatment between men and women, which is the purpose of Directive

\footnotetext{
${ }^{57}$ Association belge des Consommateurs Test-Achats and Others, above n 5, para. 20.

58 Ibid., para. 26.

${ }^{59}$ Ibid., para. 30.
} 
2004/113, and [was] incompatible with Articles 21 and 23 of the Charter'. ${ }^{60}$ Consequently, the ECJ decided to consider that provision to be invalid upon the expiry of an appropriate transitional period, i.e. 21 December $2012 .^{61}$

It follows from the foregoing that, just as when testing the compatibility of a national measure with EU law, ${ }^{62}$ the ECJ also verifies whether there are internal inconsistencies as between secondary EU law and hierarchically superior rules of EU law. The ruling of the ECJ suggests that it focuses on the contextual aspects of the proportionality principle, i.e. on the consistency of the EU measure in question. In other words, the principle of proportionality is not applied in an abstract fashion, "but as a part of the legal and factual context in which the [contested] measure operates'. ${ }^{63}$

\section{Concluding remarks}

Vodafone, Volker und Markus Schecke and Test-Achats are three recent judgments which were delivered after the entry into force of the Treaty of Lisbon. To some extent, these judgments reveal that, when examining the validity of EU policy measures, the ECJ is not reluctant to follow an approach that focuses on improving the decision-making process of the EU institutions, rather than on second-guessing their substantive findings.

As Vodafone shows, 'process review' is an interesting way of making sure that, in areas where the EU legislator enjoys broad discretion, the latter does not commit abuses. 'Process review' increases judicial scrutiny over the decision-making process of the EU institutions. However, it prevents the ECJ from intruding into the realm of politics. Moreover, by inviting the political institutions of the EU to enhance the rationalization of their decision-making process, the ECJ enforces the structure put in place by the authors of the Treaties. Whilst 'process review' shows due

\footnotetext{
${ }^{60}$ Ibid., para. 32.

${ }^{61} 21$ December 2012 is the date in which the decision to derogate from the principle of equal treatment between men and women laid down in Article 5(2) of Directive 2004/133 had to be reviewed by the Member State concerned.

62 See e.g. Joined Cases C-338/04, C-359/04 and C-360/04 Placanica and Others [2007] ECR I-1891; Case C-500/06 Corporación Dermoestética [2008]ECR I-5785; Case C-169/07 Hartlauer [2009] ECR I-1721; Joined Cases C-570/07 and C-571/07 Blanco Pérez and Chao Gómez, judgment of 1 June 2010, not yet reported.

${ }^{63}$ G. Mathisen, 'Consistency and Coherence as Conditions for Justification of Member State Measures Restricting Free Movement' (2010) 47 Common Market Law Review 1021, at 1040.
} 
deference to the expertise and higher institutional capacities of policy makers, it may be the only way of judicially enforcing principles that have a clear political nature, such as the principle of subsidiarity.

Moreover, 'process review' should always precede substantive judicial review in order to allow the ECJ to make use of its 'passive virtues' ${ }^{64}$ by avoiding unnecessary substantive conflicts with the EU political institutions. In my view, the $E C J$ is more respectful of the prerogatives of the political institutions of the EU if it rules that, when adopting the contested act, those institutions failed to take into consideration all the relevant interests at stake, than if it questions their policy choices by reference to its own view of the issues involved. This is precisely what the ECJ did in Volker und Markus Schecke.

Last but not least, Test-Achats stresses the importance of consistency. By looking at the contextual aspects of the principle of proportionality, not only is the ECJ enhancing the legitimacy of the EU legislator when the latter imposes limits on fundamental rights, but also its own judicial legitimacy. It shows that the ECJ is ready to declare invalid an EU provision which, in addition to derogating from a fundamental right, gives rise to contradictions with the EU act of which it forms part.

Unlike the U.S. academic debate over structuralism, the purpose of my contribution was not to prove the operability (or inoperability) of the 'substance vs. process' divide in the context of the EU legal order. Instead, I limited myself to showing the advantages of reviewing the different procedural steps taken by the EU political institutions when adopting an act of general application. In that regard, it seems to me that an increased judicial control of the decision-making process does not imply that judges should take a more pro-active stand whereby the latter replace the substantive choices made by the EU political institutions with their own. Nor should a process-oriented review be equated with judicial surrender. On the contrary, more often than not, courts can contribute to aligning political decisions with the structure set out in the Treaties if they provide incentives to improve the rationality of the decision-making process of policy makers.

\footnotetext{
${ }^{64}$ Term borrowed from A. Bickel, The Least Dangerous Branch: the Supreme Court at the Bar of Politics, $2^{\text {nd }}$ Ed (New Haven, Yale University Press, 1962).
} 


\section{RESEARCH PAPERS IN LAW}

1/2003, Dominik Hanf et Tristan Baumé, "Vers une clarification de la répartition des compétences entre l'Union et ses Etats Membres? Une analyse du projet d'articles du Présidium de la Convention".

2/2003, Dominik Hanf, "Der Prozess der europäischen Integration in Belgien. Voraussetzung und Rahmen der Föderalisiserung eines ehemaligen Einheitsstaats".

3/2003, Dominik Hanf, "Talking with the "pouvoir constituant" in times of constitutional reform: The European Court of Justice on Private Applicants' Access to Justice".

4/2003, Horst Dippel, "Conventions in Comparative Constitutional Law".

5/2003, Ludwig Krämer, "Access to Environmental Information in an Open European Society - Directive 2003/4".

6/2003, Ludwig Krämer, “Uberlegungen zu Ressourceneffizienz und Recycling”.

7/2003, Ludwig Krämer, "The Genesis of EC Environmental Principles".

8/2003, Takis Tridimas, "The European Court of Justice and the Draft Constitution: A Supreme Court for the Union?".

1/2004, Dominik Hanf et Pablo Dengler, "Accords d'association”.

2/2004, David Mamane, "Reform der EU-Wettbewerbsregeln für TechnologietransferVerträge: Einfahrt in den sicheren Hafen?".

3/2004, Donald Slater and Denis Waelbroeck, "Meeting Competition : Why it is not an Abuse under Article 82".

4/2004, Jacques Bourgeois and Tristan Baumé, "Decentralisation of EC Competition Law Enforcement and General Principles of Community Law".

5/2004, Rostane Mehdi, "Brèves observations sur la consécration constitutionnelle d'un droit de retrait volontaire".

1/2005, Jacques Pelkmans, "Subsidiarity between Law and Economics".

2/2005, Koen Lenaerts, "The Future Organisation of the European Courts".

3/2005, John A.E. Vervaele, "The Europeanisation of Criminal Law and the Criminal Law Dimension of European Integration". 
4/2005, Christine Reh and Bruno Scholl, "The Convention on the Future of Europe: Extended Working Group or Constitutional Assembly?"

5/2005, John A.E. Vervaele, "European Criminal Law and General Principles of Union Law".

6/2005, Dieter Mahncke, "From Structure to Substance: Has the Constitutional Treaty improved the Chances for a Common Foreign and Security Policy?".

1/2006, Dominik Hanf, “Le développement de la citoyenneté de l'Union européenne".

2/2006, Vassilis Hatzopoulos, Thien Uyen Do, "The Case Law of the ECJ concerning the Free Provision of Services : 2000 - 2005".

3/2006, Dominik Hanf, "Réformes institutionnelles sans révision du traité?", (document de discussion).

4/2006, Elise Muir, "Enhancing the effects of EC law on national labour markets, the Mangold case".

5/2006, Vassilis Hatzopoulos, "Why the Open Method of Coordination (OMC) is bad for you: a letter to the EU".

6/2006, Vassilis Hatzopoulos, "The EU essential facilities doctrine".

7/2006, Pablo Ibáñez Colomo, "Saving the Monopsony: Exclusivity, Innovation and Market Power in the Media Sector".

1/2007, Pablo Ibáñez Colomo, "The Italian Merck Case".

2/2007, Imelda Maher, "Exploitative Abuses: Which Competition Policy, Which Public Policy?".

3/2007, Vassilis Hatzopoulos, "With or without you... judging politically in the field of Area of Freedom, Security and Justice?".

4/2007, Matteo Pierangelo Negrinotti, "The AstraZeneca Case".

5/2007, Vassilis Hatzopoulos, "Que reste-t-il de la directive sur les services?".

6/2007, Vassilis Hatzopoulos, "Legal Aspects in Establishing the Internal Market for services".

7/2007, Vassilis Hatzopoulos, "Current Problems of Social Europe".

1/2008, Vassilis Hatzopoulos, "Public Procurement and State Aid in National Healthcare Systems".

2/2008, Vassilis Hatzopoulos, "Casual but Smart: The Court's new clothes in the Area of Freedom Security and Justice (AFSJ) after the Lisbon Treaty".

3/2008, Takis Tridimas and José A. Gutiérrez-Fons, "EU Law, International Law and Economic Sanctions against Terrorism: The Judiciary in Distress?". 
4/2008, Ludwig Krämer, "Environmental judgments by the Court of Justice and their duration".

5/2008, Donald Slater, Sébastien Thomas and Denis Waelbroeck, "Competition law proceedings before the European Commission and the right to a fair trial: no need for reform?".

$1 / 2009$, Inge Govaere, "The importance of International Developments in the caselaw of the European Court of Justice: Kadi and the autonomy of the EC legal order".

2/2009, Vassilis Hatzopoulos, "Le principe de reconnaissance muTEUlle dans la libre prestation de services".

3/2009, Dominik Hanf, "L'encadrement constitutionnel de l'appartenance de l'Allemagne à l'Union européenne. L'apport de l'arrêt «Lisbonne » de la Cour constitutionnelle fédérale".

1/2010, Vassilis Hatzopoulos, "Liberalising trade in services: creating new migration opportunities?"

2/2010, Vassilis Hatzopoulos \& Hélène Stergiou, "Public Procurement Law and Health care: From Theory to Practice"

3/2010, Dominik Hanf, "Vers une précision de la Europarechtsfreundlichkeit de la Loi fondamentale - L'apport de l'arrêt « rétention des données » et de la décision « Honeywell » du BVerfG"

1/2011, Nicoleta Tuominen, "Patenting Strategies of the EU Pharmaceutical Industry - Crossroad between Patent Law and Competition Policy"

2/2011, Dominik Hanf, "The ENP in the light of the new "neighbourhood clause" (Article 8 TEU)"

3/2011, Slawomir Bryska, "In-house lawyers of NRAs may not represent their clients before the European Court of Justice - A case note on UKE (2011)"

4/2011, Ann Fromont et Christophe Verdure, "La consécration du critère de l'« accès au marché » au sein de la libre circulation des marchandises : mythe ou réalité ?"

5/2011, Luca Schicho, "Legal privilege for in-house lawyers in the light of AKZO: a matter of law or policy?"

6/2011, Vassilis Hatzopoulos, "The concept of 'economic activity' in the EU Treaty: From ideological dead-ends to workable judicial concepts"

1/2012, Koen Lenaerts, "The European Court of Justice and Process-oriented Review" 